Web Site: https://jutq.utq.edu.iq/index.php/main

Email: journal@jutq.utq.edu.iq

\title{
Topological Insulators in Bi2Se3 Family Nanostructured Thin Films: Study Topological Nature and Surface states
}

https://doi.org/10.32792/utq/utj/vol12/1/5

Fouad N. Ajeel, Mohammed H. Mohammed, Rawaa A. Abd Ali

Department of Physics, College of Science, Thi Qar

University, Nassiriya, IRAQ

E-mail: fouadnimr2@gmail.com

Abstract: Topological insulators represent new states of quantum matter with an insulating bulk gap and gapless edges on surface states. Recently, $\mathrm{Bi} 2 \mathrm{Se} 3$ family (such as $\mathrm{Bi} 2 \mathrm{O} 3, \mathrm{Bi} 2 \mathrm{~S} 3, \mathrm{Bi} 2 \mathrm{Te} 3$ and $\mathrm{Bi} 2 \mathrm{Po} 3$ ) nanostructured thin films have been proposed as three-dimensional topological insulators with a single Dirac cone on the surface. In this study, we take the system as a rhombohedral crystal structure has a layered structure with three quintuple layers $(\mathrm{QL})$, in each $\mathrm{QL}$, there are five atomic planes. Based on the density functional theory (DFT), we investigate the electronic band structure, which exhibits the surface states of Bi2Se3 family nanostructured thin films. In additionally, we calculated the density of states (DOS) around the Fermi energy, which nicely explains the Dirac cone inside the bulk band gap. We conclude that $\mathrm{Bi} 2 \mathrm{O} 3$ thin film is a strong topological insulator, which can be used in important electronic applications.

Keywords: topological insulators, DFT, thin films, nanostructure, DOS.

العوازل الطبوغرافية في اللأفشية الرقيقة عائلة Bi2Se3 ذات التركيب النانوي: دراسة الطبيعة الطبوغرافية والحالات السطحية الطية عالة فئة

$$
\text { فؤاد نمر عجيل , محمد هلول محمد, رواء عباس عبد علي }
$$




\section{University of Thi-Qar Journal Vol.12 No.1 Mar 2017 \\ Web Site: https://jutq.utq.edu.iq/index.php/main \\ Email: journal@jutq.utq.edu.iq}

\section{قسم الفيزياء، كلية العلوم، جامعة ذي قار، الناصرية ، العراق}

الملخص: تمثل العوازل الطبوغر افية حالات جديدة من المواد الكمية التي تمتلك فجوة العازل

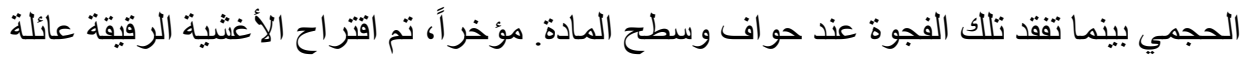

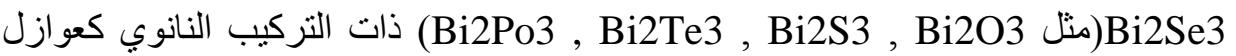
طبو غر افية ثلاثية الأبعاد لها مخروط دير الك واحد على السطح. في هذه الدراسة أخذنا النظام

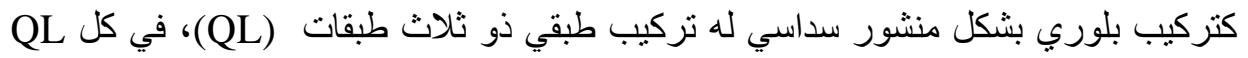

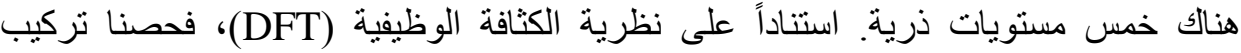

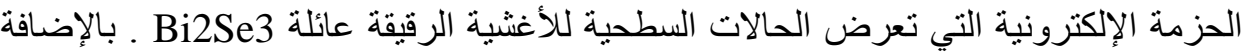

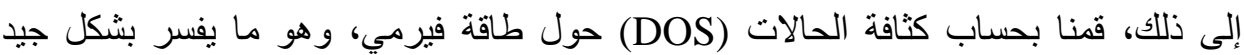

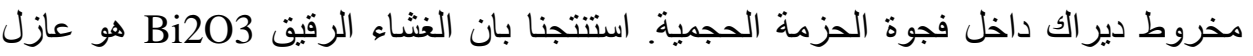
طبو غر افي قوي، و الذي يمكن استخدامه في التطبيقات الالكترونية الهامة.

الكلمات المفتاحية: العوازل الطبو غر افية, DFT , الأغشية الرقيقة , تركيب نانوي , DOS.

\section{Introduction}

Topological insulators are the electronic materials that have a bulk band gap, but still support conducting states their edge or surface [1-3]. It can be shown these states are topologically protected due to a nontrivial topological index of the material and these states cannot be removed by any distortions [1, 4]. The energy-momentum relation of these surface states has a Dirac cone structure similar to that of the graphene [1]. Therefore, topological insulators constitute a new class of quantum matter that may some day be exploited in potential applications involving future photonics, quantum computing, and spintronic devices, have attracted great attention in materials science and condensed matter physics [5-7].

These topological materials have been theoretically predicted and experimentally observed in a variety of systems, for instance BiSb alloys, $\mathrm{Bi}_{2} \mathrm{Se}_{3}$ crystals, and $\mathrm{HgTe}$ quantum wells [2, 3, 8-11]. Now, there are a lot of studies are in progress on the $\mathrm{Bi}_{2} \mathrm{Se}_{3}$ family of compounds (i.e. $\mathrm{Bi}_{2} \mathrm{O}_{3}$, $\mathrm{Bi}_{2} \mathrm{~S}_{3}, \mathrm{Bi}_{2} \mathrm{Se}_{3}, \mathrm{Bi}_{2} \mathrm{Te}_{3}$ and $\mathrm{Bi}_{2} \mathrm{Po}_{3}$ ), and quantitative studies and comparison with experiments are of increasing importance. These compounds are chemically very stable, stoichiometric, and easy to 


\section{University of Thi-Qar Journal Vol.12 No.1 Mar 2017 \\ Web Site: https://jutq.utq.edu.iq/index.php/main \\ Email: journal@jutq.utq.edu.iq}

synthesize, and yet their surface states are very simple. In this family, the existence of such surface states has been experimentally confirmed on samples ranging from bulk to thin film [3, 11-14].

In order to study the behavior of both the bulk and the surface states simultaneously. This behavior is necessary to identify its topological nature, and demanding calculations are involved. One of the main methods is the density functional theory (DFT), which is using to demonstrate the topological nature as well as the details of the surface states can all be well reproduced [15-18].

In this paper, we describe the crystal structure of the $\mathrm{Bi}_{2} \mathrm{Se}_{3}$ family of compounds. Based on the DFT, we study the topological nature and surface properties through the electronic band structure and the density of states (DOS). Our theoretical results are analyzed and discusses to find the nanostructured thin film has a characteristic of a topological insulator.

\section{Computational details}

We have chosen $\mathrm{Bi}_{2} \mathrm{Se}_{3}$ nanostructured thin film as an example of the $\mathrm{Bi}_{2} \mathrm{Se}_{3}$ family of compounds, where $\mathrm{Bi}_{2} \mathrm{Se}_{3}$ is rhombohedral crystal structure and belongs to space group $\mathrm{D}_{3 d}^{5}$, as seen in Fig.1. The electronic band structure and the DOS calculations were carried out using approach the local-density approximation (LDA) to DFT with the Atomistix toolkit (ATK) software package. The bulk electronic structure is calculated using the lattice constants $a=b=4.138 \AA$ and $c=28.64 \AA$, and internal coordinates $\mu=0.399$ for Bi sites and $v=0.206$ for Se sites [2, $15]$. 


\section{University of Thi-Qar Journal Vol.12 No.1 Mar 2017}

Web Site: https://jutq.utq.edu.iq/index.php/main

\section{Email: journal@jutq.utq.edu.iq}

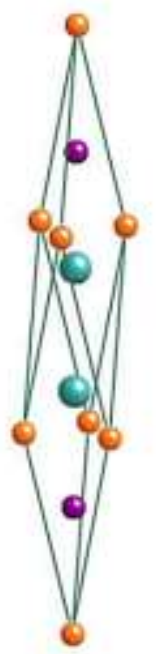

(a)

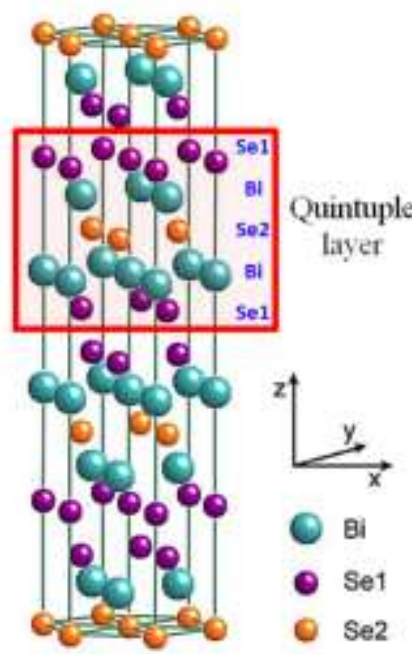

(b)

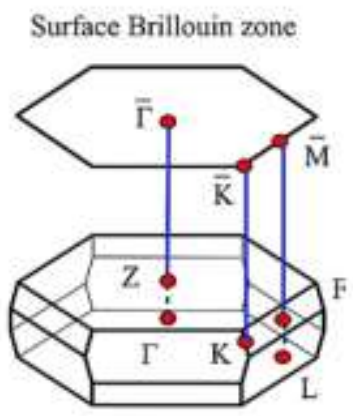

Bulk Brillouin zone

(c)

Fig. 1. (a) Rhombohedral primitive and (b) the hexagonal crystal structure of the $\mathrm{Bi}_{2} \mathrm{Se}_{3}$ nanostructured thin film, where a quintuple layer with five atomic layers $\mathrm{Se}_{1}-\mathrm{Bi}-\mathrm{Se}_{2}-\mathrm{Bi}-\mathrm{Se}_{1}$ sequence is presented by the red square. (c) The surface and bulk Brillouin zone (BZ) along with different high symmetry points [19].

In order to investigate the electronic structure of the surface, we take the crystal structure with both rhombohedral and hexagonal axes, see Fig.1(a). The lattice has a layered structure with three basic unit cells, one unit cell named a quintuple layer (QL), weakly bound to each other by the van der Waals forces. In each QL, five atomic planes with atomic order $\mathrm{Se} 1-\mathrm{Bi}-\mathrm{Se}_{2}-\mathrm{Bi}-\mathrm{Se}_{1}$ where two nonequivalent $\mathrm{Se}$ layers are denoted by $\mathrm{Se}_{1}$ and $\mathrm{Se}_{2}$, see Fig.1(b), and the chemical bond between $\mathrm{Bi}$ and $\mathrm{Se}$ atoms is of the covalent-ionic type. We take $\mathrm{Se}_{2}$ to be at the origin coordinate $(0,0,0)$; then two Bi sites are at internal coordinates $( \pm \mu, \pm \mu, \pm \mu)$, and two $\mathrm{Se}_{1}$ are at $( \pm v, \pm v, \pm v)$. Figure 1(c) shows the bulk and surface Brillouin zones with different high symmetry K points. For (111) surface of $\mathrm{Bi}_{2} \mathrm{Se}_{3}$, the time reversal invariant momenta are the high symmetry points, $\Gamma$ and $\mathrm{M}[2,15]$. 


\section{University of Thi-Qar Journal Vol.12 No.1 Mar 2017 \\ Web Site: https://jutq.utq.edu.iq/index.php/main \\ Email: journal@jutq.utq.edu.iq}

\section{Results and discussion}

The electron band structures for the $\mathrm{Bi}_{2}$ pure and $\mathrm{Bi}_{2} \mathrm{O}_{3}, \mathrm{Bi}_{2} \mathrm{~S}_{3}, \mathrm{Bi}_{2} \mathrm{Se}_{3}$, $\mathrm{Bi}_{2} \mathrm{Te}_{3}, \mathrm{Bi}_{2} \mathrm{Po}_{3}$ nanostructured thin films have been calculated and shown in Fig. 2. Electronic bands are present around the Fermi level $E_{\mathrm{F}}$ at the $\Gamma$ point (center of the Brillouin zone), which represent the surface states. The band gap is the energy difference between the lowest point of the conduction band (conduction band edge) and the highest point of the valence band (valence band edge). The band gap of the nanostructured thin films are calculated at $\Gamma$ point, and we found that it has a direct band gap. The band gaps values for the $\mathrm{Bi}_{2}$ pure, $\mathrm{Bi}_{2} \mathrm{O}_{3}, \mathrm{Bi}_{2} \mathrm{~S}_{3}, \mathrm{Bi}_{2} \mathrm{Se}_{3}, \mathrm{Bi}_{2} \mathrm{Te}_{3}$ and $\mathrm{Bi}_{2} \mathrm{Po}$ are $0.0,0.326,0.357,0.117,0.0$, and $0.2163 \mathrm{eV}$, respectively. It is clear that the dirac cone is located inside the bulk band gap. There is a tiny gap between the valence and conduction surface bands. This is a finite size effect by using a theoretical model, which arise from the interaction of the surface bands on opposite sides of the present $\Gamma$-points the gap will be reduced.

In fact, one obtains a single valley valence-band maximum and the same for the conduction-band minimum, both occurring at the $\Gamma$-point occurring at the centre of the Brillouin zone (BZ) and we find both valleys to have an isotropic effective mass. There are some valleys for the highest valence band located in the mirror planes of the $\mathrm{BZ}$ at the $\Gamma$ point, which shows the calculated location of the valence-band maximum in the BZ. The nature of the conduction-band minimum has been studied experimentally and it is consistent with our results. Theoretical studies favorite in this field because of the experimental data on the nature of the valence-band maximum are limited. On the basis of an early galvanomagnetic measurement, a single-valley valence-band maximum located at the $\Gamma$-point was postulated. This is confirmed by the present calculations, see Fig. 2. There are some valleys for the highest valence band located in the mirror planes of the $\mathrm{BZ}$ at the $\Gamma$-point, which shows the calculated location of the valence-band maximum in the BZ, see Fig. 2(c and d).

The DOS of studies nanostructured thin films are shown in Fig. 3. As 


\section{University of Thi-Qar Journal Vol.12 No.1 Mar 2017 \\ Web Site: https://jutq.utq.edu.iq/index.php/main \\ Email: journal@jutq.utq.edu.iq}

stated in the introduction, the electronic structure of the surface states close to the Fermi level resembles that of a Dirac cone, where the electron momentum depends linearly on the energy. Since the surface states are the only states present inside the bulk energy gap, we should expect the electronic DOS close to Fermi level to be linear. We see the expected linear dependence of the DOS on energy, as illustrated in Fig. 3. The sharp increase with $\mathrm{Bi}_{2} \mathrm{O}_{3}$ in DOS close to the Fermi level are due to the lowest bulk valence bands.

It is noted from the DOS that the valence and conduction bands consist of many sharp, but the maximum is in surface states near the Fermi level for $\mathrm{Bi}_{2} \mathrm{O}_{3}$ thin film. For the $\mathrm{Bi}_{2} \mathrm{O}_{3}$, the electron states in the vicinity of the gap region consist of the sharp, since all other sharps lie far away in energy. Figs. 2(b) and 3 have been presented significant effect of $\mathrm{Bi}_{2} \mathrm{O}_{3}$. And addition, the $\mathrm{Bi}_{2} \mathrm{O}_{3}$ open new concept for the thin film, which is quantization energy levels and behavior of thin film as nanoparticle.

Figure 4 clearly shows the topological nature and surface states of $\mathrm{Bi}_{2} \mathrm{O}_{3}$ thin film. Some surface states crossing the Fermi level (indicated by blue and red dots); bands (indicated by blue dot) form a single degenerate band immediately below the Fermi energy, while bands (indicated by red dot) form a degenerate band above the Fermi level. The bulk valence bands are below those surface states (indicated by green dot). Previous results confirm that the $\mathrm{Bi}_{2} \mathrm{O}_{3}$, thin film is a strong topological insulator.

\section{4- Conclusions}

In summary, the topological nature and the surface states for the $\mathrm{Bi}_{2} \mathrm{O}_{3}$ family nanostructured thin films are investigated based on the LDA to the DFT. The calculations include the electronic band structure and the DOS of the bulk and the surface for the $\mathrm{Bi}_{2} \mathrm{O}_{3}$ family nanostructured thin films. Our results show that, the $\mathrm{Bi}_{2} \mathrm{O}_{3}$ thin film has topological nature and surface states, so the $\mathrm{Bi}_{2} \mathrm{O}_{3}$ thin film is a strong topological insulator, which can be used in many important applications. 


\section{University of Thi-Qar Journal Vol.12 No.1 Mar 2017 \\ Web Site: https://jutq.utq.edu.iq/index.php/main \\ Email: journal@jutq.utq.edu.iq}

\section{Acknowledgements}

We are indebted to Dr. Falah Hassan Hanon from Thi Qar University for helpful discussions. We also thank Iraqi Ministry of Higher Education and Scientific Research for its support of scientific researches through the Iraqi Virtual Science Library (IVSL). 


\section{University of Thi-Qar Journal Vol.12 No.1 Mar 2017 \\ Web Site: https://jutq.utq.edu.iq/index.php/main \\ Email: journal@jutq.utq.edu.iq}

(a) $\mathrm{Bi}_{2}$ pure

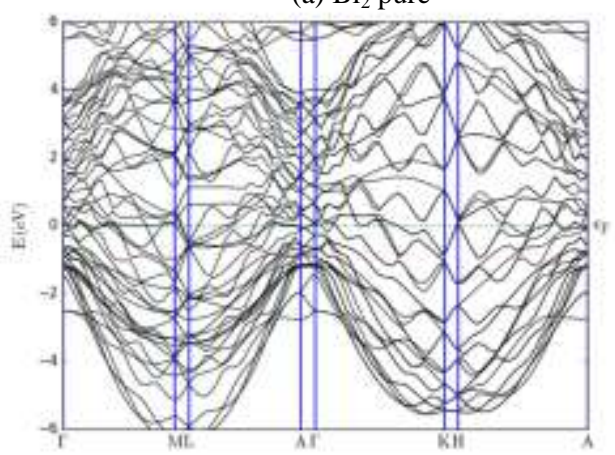

(c) $\mathrm{Bi}_{2} \mathrm{~S}_{3}$

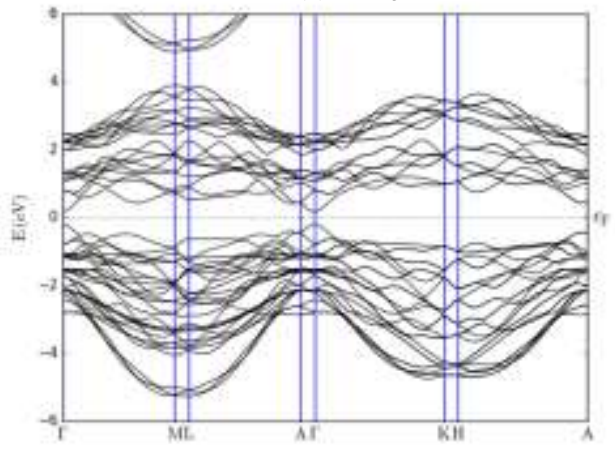

(e) $\mathrm{Bi}_{2} \mathrm{Te}_{3}$

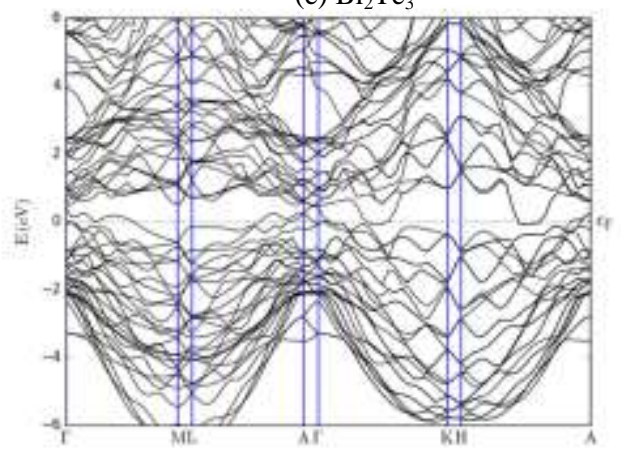

(b) $\mathrm{Bi}_{2} \mathrm{O}_{3}$

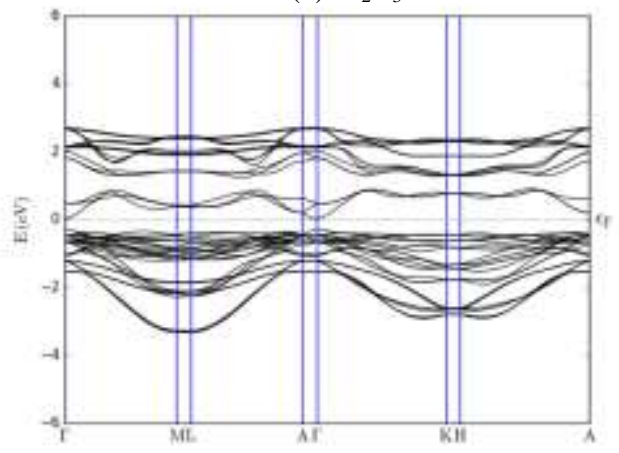

(d) $\mathrm{Bi}_{2} \mathrm{Se}_{3}$

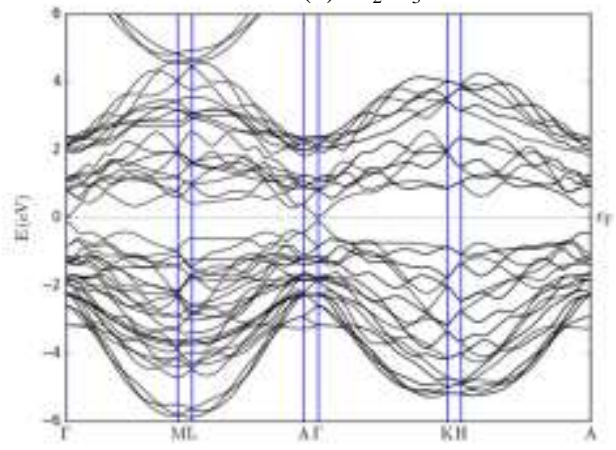

(f) $\mathrm{Bi}_{2} \mathrm{Po}_{3}$

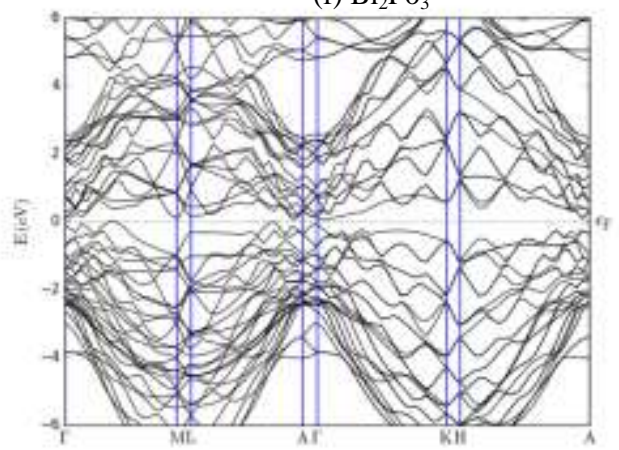

Fig. 2. The comparison of electronic band structures for the nanostructured thin films under study. Where $\Gamma, \mathrm{M}, \mathrm{L}, \mathrm{A}, \mathrm{K}, \mathrm{H}$ represent a reciprocal lattice vectors in Brillouin zones for a lattice. 
University of Thi-Qar Journal Vol.12 No.1 Mar 2017

Web Site: https://jutq.utq.edu.iq/index.php/main

Email: journal@jutq.utq.edu.iq

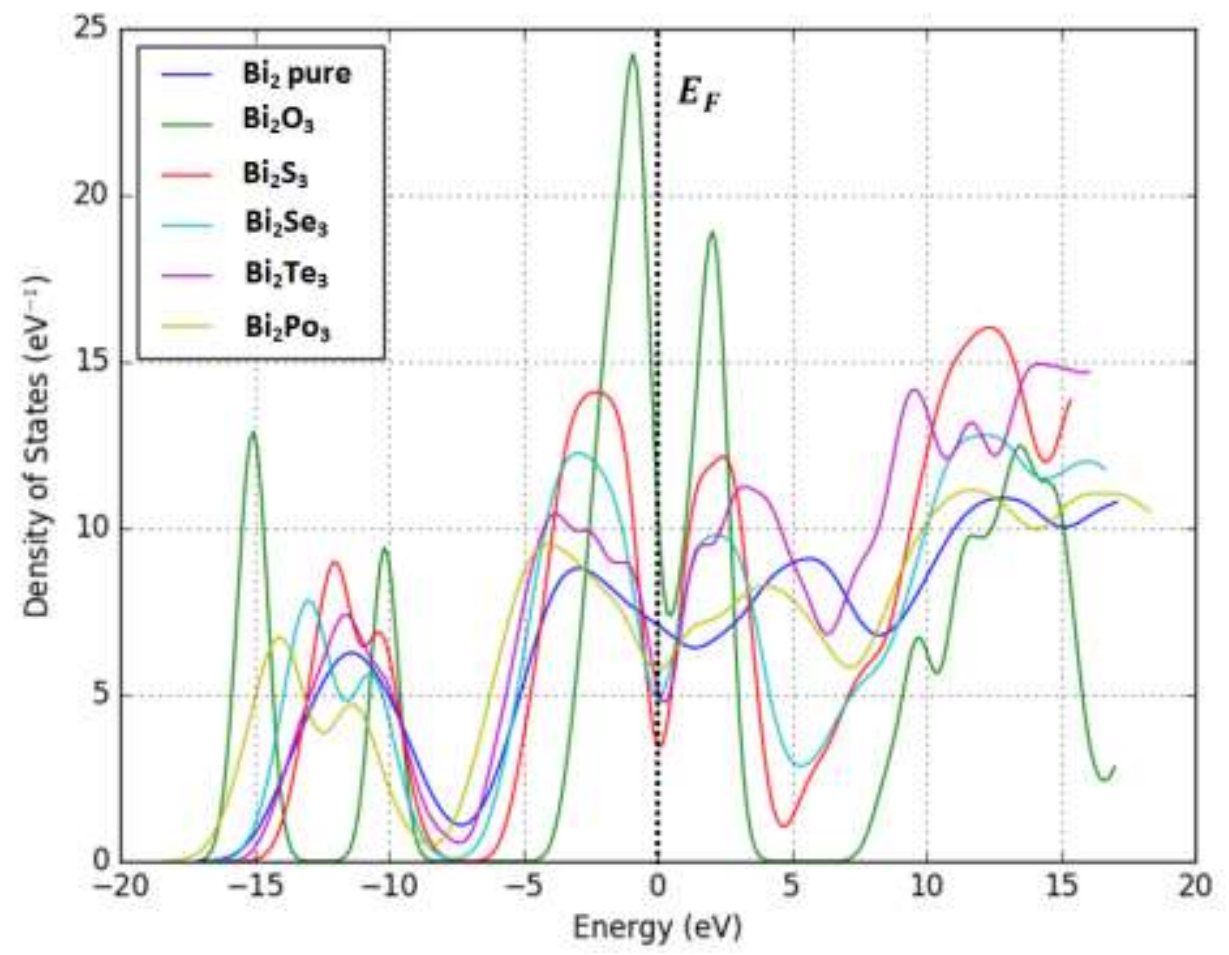

Fig. 3. The comparison of the electronic density of states of the nanostructured thin films under study.

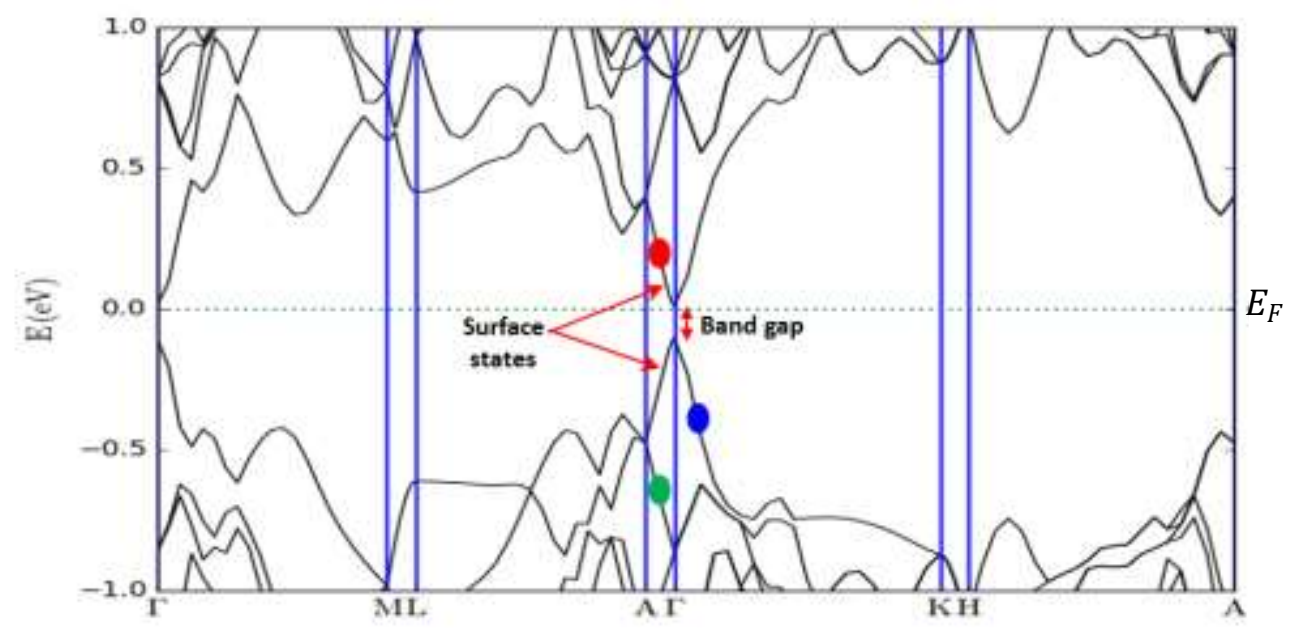

Fig. 4. The electronic band structures for the $\mathrm{Bi}_{2} \mathrm{O}_{3}$ nanostructured thin film. 


\section{University of Thi-Qar Journal Vol.12 No.1 Mar 2017 \\ Web Site: https://jutq.utq.edu.iq/index.php/main \\ Email: journal@jutq.utq.edu.iq}

\section{References}

[1] M. Z. Hasan and C. L. Kane, "Colloquium: topological insulators," Reviews of Modern Physics, vol. 82, no. 4, p. 3045, 2010.

[2] H. Zhang, C.-X. Liu, X.-L. Qi, X. Dai, Z. Fang, and S.-C. Zhang, "Topological insulators in Bi2Se3, Bi2Te3 and Sb2Te3 with a single Dirac cone on the surface," Nature physics, vol. 5, no. 6, pp. 438-442, 2009.

[3] Y. L. Chen et al., "Experimental realization of a three-dimensional topological insulator, Bi2Te3," Science, vol. 325, no. 5937, pp. 178-181, 2009.

[4] B. A. Bernevig and T. L. Hughes, Topological insulators and topological superconductors. Princeton University Press, 2013.

[5] X.-L. Qi and S.-C. Zhang, "The quantum spin Hall effect and topological insulators," Physics Today, vol. 63, no. 1, pp. 33-38, 2010.

[6] J. E. Moore, "The birth of topological insulators," Nature, vol. 464, no. 7286, pp. 194-198, 2010.

[7] X.-L. Qi and S.-C. Zhang, "Topological insulators and superconductors," Reviews of Modern Physics, vol. 83, no. 4, p. 1057, 2011.

[8] B. A. Bernevig and S.-C. Zhang, "Quantum spin Hall effect," Physical Review Letters, vol. 96, no. 10, p. 106802, 2006.

[9] L. Fu, C. L. Kane, and E. J. Mele, "Topological insulators in three dimensions," Physical Review Letters, vol. 98, no. 10, p. 106803, 2007.

[10] D. Hsieh et al., "A topological Dirac insulator in a quantum spin Hall phase," Nature, vol. 452, no. 7190, pp. 970-974, 2008.

[11] Y. Xia et al., "Observation of a large-gap topological-insulator class with a single Dirac cone on the surface," Nature physics, vol. 5, no. 6, pp. 398-402, 2009.

[12] G. Zhang et al., "Quintuple-layer epitaxy of high-quality Bi2Se3 thin films for topological insulator," arXiv preprint arXiv:0906.5306, 2009.

[13] Y.-Y. Li et al., "Growth dynamics and thickness-dependent electronic structure of topological insulator $\mathrm{Bi} 2 \mathrm{Te} 3$ thin films on $\mathrm{Si}$," arXiv preprint arXiv:0912.5054, 2009.

[14] T. Zhang et al., "Experimental demonstration of topological surface states protected by time-reversal symmetry," Physical Review Letters, vol. 103, no. 26, p. 266803, 2009.

[15] W. Zhang, R. Yu, H.-J. Zhang, X. Dai, and Z. Fang, "First-principles studies of the three-dimensional strong topological insulators Bi2Te3, Bi2Se3 and Sb2Te3," New Journal of Physics, vol. 12, no. 6, p. 065013, 2010.

[16] Y. Zhao et al., "Interlayer vibrational modes in few-quintuple-layer Bi 2 Te 3 and $\mathrm{Bi} 2 \mathrm{Se} 3$ two-dimensional crystals: Raman spectroscopy and firstprinciples studies," Physical Review B, vol. 90, no. 24, p. 245428, 2014.

[17] J. Chang, L. F. Register, and S. K. Banerjee, "Topological insulator Bi2Se3 thin films as an alternative channel material in metal-oxide-semiconductor fieldeffect transistors," Journal of Applied Physics, vol. 112, no. 12, p. 124511, 2012. 


\section{University of Thi-Qar Journal Vol.12 No.1 Mar 2017 \\ Web Site: https://jutq.utq.edu.iq/index.php/main \\ Email: journal@jutq.utq.edu.iq}

[18] P.-H. Chang, T. Markussen, S. r. Smidstrup, K. Stokbro, and B. K. Nikolić, "Nonequilibrium spin texture within a thin layer below the surface of currentcarrying topological insulator Bi 2 Se 3: A first-principles quantum transport study," Physical Review B, vol. 92, no. 20, p. 201406, 2015.

[19] D. Biswas and K. Maiti, "Anomalies in the electronic structure of Bi (2) Se (3)," arXiv preprint arXiv:1502.03631, 2015. 